\title{
Long-term changes in the water quality and fish community of a large boreal lake affected by rising water temperatures and nutrient-rich sewage discharges - with special emphasis on the European perch
}

\author{
A. Voutilainen ${ }^{(1)}, \mathrm{H}$. Huuskonen ${ }^{(1)}$ \\ Received March 22, 2010 / Reçu le 22 mars 2010 \\ Revised June 7, 2010 / Révisé le 7 juin 2010 \\ Accepted June 7, 2010 / Accepté le 7 juin 2010
}

Key-words: eutrophication, fish, freshwater lake, global warming, pulp mill effluent

\section{ABSTRACT}

In this study, we report the changes in the water quality and fish community of a large boreal lake (Lake Pyhäselkä, Finland) in 1975-2005, when the lake was affected first by industrial and municipal sewage discharge and then by rising water temperatures. In the 1980s, the lake's trophic state proceeded from oligotrophic to mesotrophic, which favoured cyprinids. The increased cyprinid density strengthened the competition pressure on perch (Perca fluviatilis) reducing the growth rates of young perch. The lake's trophic state shifted from mesotrophic back to oligotrophic in the 1990s as a result of effective treatment of sewage waters. The water temperature in Lake Pyhäselkä rose from the beginning to the end of the monitoring period. The higher temperature favoured perch. In future, the warming may benefit pikeperch (Sander lucioperca) even more than perch. This will probably affect the perch population, as pikeperch prey effectively on perch.

\section{RÉSUMÉ}

Changements à long terme dans la qualité de l'eau et la communauté piscicole d'un grand lac boréal affecté par le réchauffement des eaux et les déversements d'effluents riches en nutriments - avec l'accent mis sur la perche

Mots-clés : eutrophication, poisson, lac, réchauffement global, effluent de papeterie
Dans cette étude, nous rendons compte des changements dans la qualité des eaux et la communauté piscicole d'un grand lac boréal (Lac Pyhäselkä, Finlande) de 1975 à 2005, quand le lac a été affecté par des effluents industriels et domestiques et par le réchauffement des eaux. Dans les années 1980, le statut trophique est passé d'oligotrophique à mésotrophique, ce qui favorise les cyprinidés. La densité accrue des cyprinidés a augmenté la pression de compétition sur la perche (Perca fluviatilis) réduisant le taux de croissance des jeunes perches. Le statut trophique du lac est retourné de mésotrophique à oligotrophique dans les années 1990 suite au traitement effectif des effluents industriels et domestiques. La température des eaux du lac Pyhäselkä a augmenté du début à la fin de la période de suivi. Les températures plus fortes favorisent la perche. Dans le futur, le réchauffement devrait bénéficier plus au sandre (Sander lucioperca) qu'à la perche. Cela affectera probablement la population de perches, puisque la perche est une proie du sandre.

(1) Ecological Research Institute, University of Eastern Finland, P.O. Box 111, Fl-80101 Joensuu, Finland, ari.voutilainen@uef.fi 


\section{INTRODUCTION}

The fish communities of freshwater lakes are modified first by the lake's trophic status and water temperature on the larger spatial and temporal scale and second by biotic interactions within and between different trophic levels. In general, fish biomass is positively related to lake productivity (Persson et al., 1991; Helminen et al., 2000; Olin et al., 2002) and water temperature (Lappalainen and Lehtonen, 1997). However, the response of fish populations to changes in lake productivity and temperature depends on the species. In the boreal region, eutrophication benefits cyprinids, such as roach (Rutilus rutilus), more than percids, such as perch (Perca fluviatilis) (Olin et al., 2002), and rising water temperature especially favours cool and warm water species (Lappalainen and Lehtonen, 1997), such as bream (Abramis brama) and pikeperch (Sander lucioperca), rather than cold water species, such as whitefish (Coregonus lavaretus). Moreover, the effects arising from the lake's productivity and water temperature are related to many geographical and physicochemical factors, including the length of the ice cover period (Gyllström et al., 2005) as well as the lake's size and the transparency of its surface water (Olden et al., 2006). Overall annual variations in the fish community tend to be lower in lakes with low water transparency, both in eutrophic and in oligotrophic lakes (Olden et al., 2006). In general, high habitat complexity and large size of a lake reduce competition and overlap in resource utilization among fish (MacLean and Magnuson, 1977; Horppila et al., 2000). The effects of fluctuating temperature on the intra- and interspecific relationships between fish (Schlosser et al., 2000) are especially strong if the overall niche space of the species is narrow - as is the case in many northern latitude lakes (Jansen and Hesslein, 2004; Lappalainen and Soininen, 2006).

Nowadays, the aquatic environment is seriously affected by two fundamental impacts: global warming and eutrophication. The effects of warming and eutrophication on the physical, chemical and biological characteristics of waters may be either straightforward or synergetic (see e.g., Schindler, 1997). In boreal freshwaters, warming is expected to shift the structure of fish communities towards percid and cyprinid dominance at the expense of salmonids (Lehtonen, 1996). Warming will benefit especially perch (Perca fluviatilis), pikeperch (Sander lucioperca) and bream (Abramis brama) (Lehtonen and Lappalainen, 1995; Lappalainen and Lehtonen, 1997). Paper and pulp mill effluents cause eutrophication in the receiving water bodies (Huuskonen et al., 2000; Karels and Niemi, 2002). In Finland, the abundance of many salmonids and other fish species that are sensitive to pollution, mainly because they require a high concentration of dissolved oxygen in the water, has been found to decrease in waters altered by the effluents from paper and pulp mills (Bagge and Hakkari, 1992; Hakkari, 1992; Hakkari and Bagge, 1992; Karels and Niemi, 2002). On the other hand, total fish biomass is usually higher in the vicinity of the mills (Hakkari, 1992; Karels and Niemi, 2002) as a consequence of increased primary production. Perch and roach are the predominant fish species in most Finnish lakes (Tammi et al., 2003). Perch is affected by paper and pulp mill effluents more than the cyprinid roach, mainly because its reproduction is physiologically more sensitive to toxicants (Karels et al., 2001).

In this study, we report long-term changes in the physical, chemical and biological water quality parameters and the fish community of a large boreal lake affected by the nutrientrich sewage discharge from a large pulp mill and a medium-sized Finnish town. We integrate the changes in water quality with the biotic interactions among fish, with a special focus on the most abundant species, i.e. perch, and discuss the role of fundamental processes such as the global warming in the changes monitored during four decades. More precisely, the following questions are addressed: (1) how did the fish community respond to the increased productivity of Lake Pyhäselkä in the 1980s and (2) how did the fish community respond to the increased water temperature of the lake from the late 1990s to the early 2000 s? We hypothesise that the higher nutrient input into the lake favoured cyprinids more than percids and the higher temperature favoured percids more than cyprinids. 


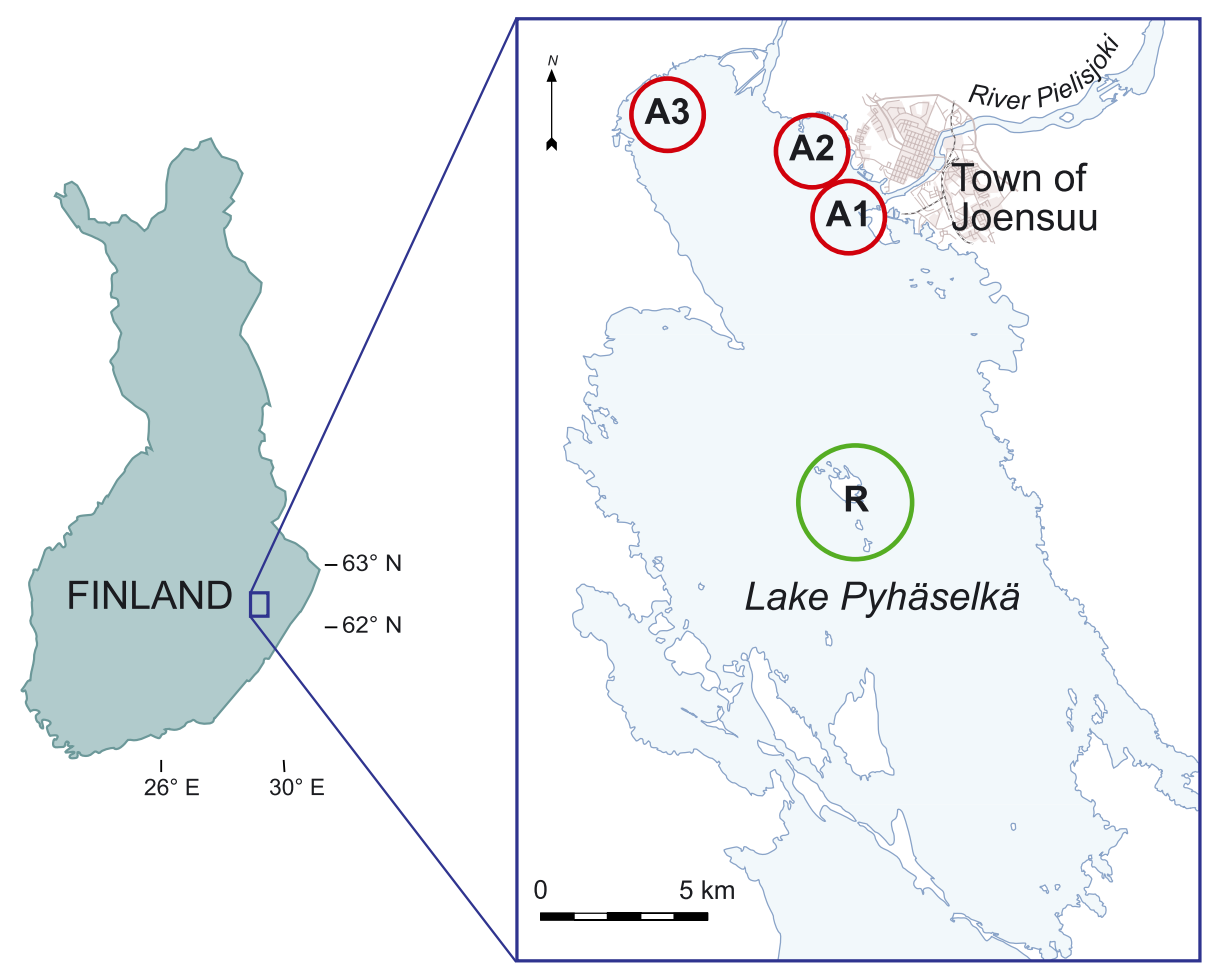

\section{Figure 1}

Location of four sampling sites in Lake Pyhäselkä (62 $\left.20^{\prime}-62^{\circ} 40^{\prime} \mathrm{N}, 29^{\circ} 33^{\prime}-29^{\circ} 56^{\prime} \mathrm{E}\right)$, Finland. The three sites affected by sewage discharge from a pulp mill and the town of Joensuu are indicated as follows: A1 = Jokisuu, $A 2=$ Noljakansaaret and A3 = Ylämylly. The reference site (Pyhäsaari) is indicated by $R$.

\section{Figure 1}

Localisation des quatre sites d'échantillonnage dans le lac Pyhäselkä (62 $\left.20^{\prime}-62^{\circ} 40^{\prime} \mathrm{N}, 29^{\circ} 33^{\prime}-29^{\circ} 56^{\prime} \mathrm{E}\right)$, Finlande. Les trois sites affectés par les décharges d'effluents de station d'épuration d'une papeterie et de la ville de Joensuu sont indiqués comme suit : A1 = Jokisuu, A2 = Noljakansaaret et A3 = Ylämylly. Le site de référence (Pyhäsaari) est indiqué par $R$.

\section{MATERIALS AND METHODS}

\section{> STUDY SITE}

Lake Pyhäselkä is situated in the boreal zone in eastern Finland $\left(62^{\circ} 20^{\prime}-62^{\circ} 40^{\prime} \mathrm{N}, 29^{\circ} 33^{\prime}-\right.$ $29^{\circ} 56^{\prime} \mathrm{E}$ ) (Figure 1). It is a large (area $263 \mathrm{~km}^{2}$, volume $2.5 \mathrm{~km}^{3}$ ), humic lake with a mean depth of $9 \mathrm{~m}$ and maximum depth of $67 \mathrm{~m}$. The lake is open with only five larger islands (area $>1 \mathrm{~km}^{2}$ ). It has a drainage basin of $24340 \mathrm{~km}^{2}$. The water of Lake Pyhäselkä is slightly acidic (average pH 6.4 in 2008) and brown (average colour of the water $90 \mathrm{mg} \mathrm{Pt.L^{-1 }}$ in 2008) with a theoretical retention time of 3.5 months. The River Pielisjoki (mean discharge $228 \mathrm{~m}^{3} \cdot \mathrm{s}^{-1}$ ) flows into the northern part of Lake Pyhäselkä, affecting its physical and chemical features. Through the river Lake Pyhäselkä receives pulp mill effluents from one of the largest pulp mills in the world, Enocell, which has produced pulp since 1967, and municipal sewage from the town of Joensuu, which at the end of 2004 had approx. 53000 inhabitants. The amount of sewage discharge, including nutrients, from the pulp mill increased towards the end of the 1980's and reached its highest level in 1987. The pulp mill was modernised in 1992 and, since then, it has effectively treated its own effluents. The waste waters from the town of Joensuu have been treated mechanically, biologically and chemically by a treatment plant located in the vicinity of the outlet of the River Pielisjoki since 1975. The treatment plant was modernised in 1987. At present, the nutrient concentrations in Lake Pyhäselkä are low (average total phosphorus $11 \mu \mathrm{g} \cdot \mathrm{L}^{-1}$ and total nitrogen $460 \mu \mathrm{g} \cdot \mathrm{L}^{-1}$ in 2008), indicating oligotrophy (Figure 2). 

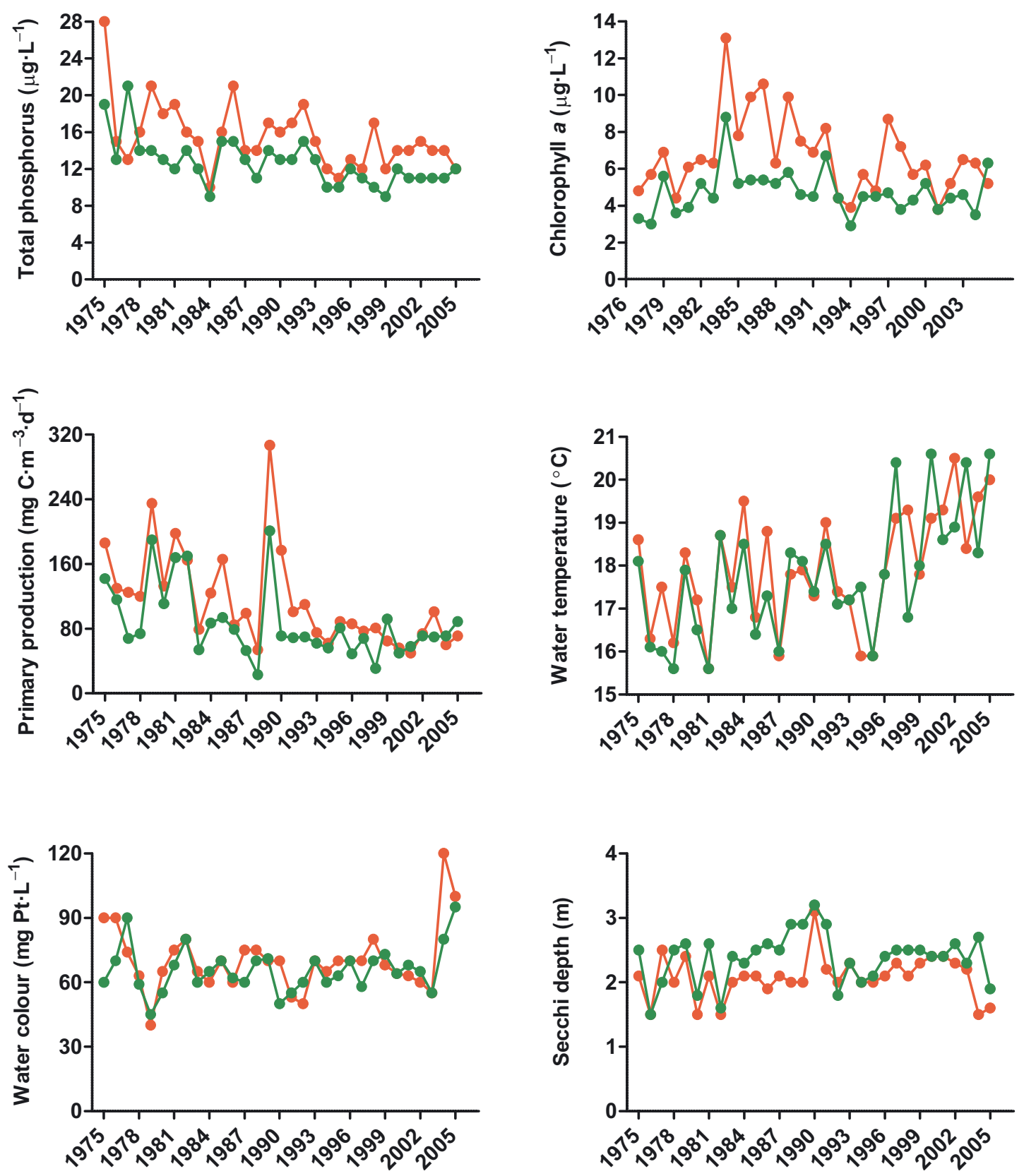

Figure 2

Physicochemical (total phosphorus concentration, temperature, colour and Secchi depth) and biological (chlorophyll a concentration and primary production of phytoplankton and bacteria) water quality parameters monitored at a depth of $1 \mathrm{~m}$ in Lake Pyhäselkä from 1975 to 2005. The parameters monitored in the area affected by sewage discharge from a pulp mill and the town of Joensuu are indicated by red symbols and a line. The parameters monitored in the reference area are indicated by green symbols and a line.

Figure 2

Paramètres physico-chimiques (concentration en phosphore total, température, couleur, profondeur du Secchi) et biologiques (concentration en chlorophylle $a$, et production du phytoplancton et des bactéries) suivis à une profondeur de $1 \mathrm{~m}$ dans le lac Pyhäselkä de 1975 à 2005. Les paramètres suivis dans la zone affectée par les effluents de papeterie et de la ville de Joensuu sont en symboles et ligne rouges, ceux de la zone de référence en symboles et ligne verts. 
From the 1970s to the present, the average surface water temperature in summer (JulyAugust) in Lake Pyhäselkä has showed a clear rising trend (Figure 2). The lake is covered by ice approximately 180 days a year ${ }^{-1}$, from December to May. During the ice-cover period in winter the water temperature in the lake's surface layer is constantly $0-1{ }^{\circ} \mathrm{C}$, whereas at the greatest depths the temperature is $\mathrm{C} .4^{\circ} \mathrm{C}$.

\section{$>$ SAMPLING}

Physical and chemical (Secchi depth, temperature, total nitrogen concentration, total phosphorus concentration and colour) and biological (chlorophyll a concentration, primary production of phytoplankton and bacteria) water quality parameters and fish have been monitored in Lake Pyhäselkä i.e. in the recipient area of industrial and municipal sewage, from the 1970s to the present. Water samples have been taken at two sites, Noljakansaaret (maximum depth $11 \mathrm{~m}$ ) and Pyhäsaari $(51 \mathrm{~m})$, several times each year in July and August. The samples have been analysed according to the following standards: SFS-EN-ISO 11905-1 (total nitrogen), withdrawn SFS 3026 (total phosphorus), SFS-EN ISO 7887 (colour), SFS 5772 (chlorophyll a) and SFS 3049 (primary production). Noljakansaaret is situated in the northern part of the lake, which is affected by the sewage discharge from the Enocell pulp mill and the town of Joensuu through the River Pielisjoki (Figure 1). The reference site, Pyhäsaari, is situated in the southern part of the lake about $9 \mathrm{~km}$ from the outlet of the River Pielisjoki (Figure 1). Fish samples have been taken with benthic and pelagic gillnets at four sites in Lake Pyhäselkä approximately every third year in May and June since 1978. Three of the sampling sites, Jokisuu, Noljakansaaret and Ylämylly, are situated in the affected, northern part of the lake, and the reference site, Pyhäsaari, is in the southern part of the lake (Figure 1). Two types of gillnets have been used as sampling gears; a benthic gillnet series (eight $30 \times 1.5 \mathrm{~m}$ nets per series with mesh sizes 12, 15, 20, 25, 35, 45, 55 and $75 \mathrm{~mm}$ from knot to knot) in 1978-1995 and a benthic/pelagic multimesh gillnet (nine $3.3 \times 1.5 \mathrm{~m}$ panels per net with mesh sizes 10, 12, 15, $20,25,30,35,45$ and $55 \mathrm{~mm}$ from knot to knot) in 1998-2005. At all four sampling sites in 1978-2005, the gillnets were placed in the areas where the water depth was less than $13 \mathrm{~m}$. The number of gillnets at each site and in each year varied from 8 to 24 , and the total number of gillnet nights was 612 . For the present study, all the gillnet catches were converted to correspond to gillnet series catches using the regression model $y=8 \times(0.021+0.695 x)$, where $y$ is the gillnet series catch and $x$ is the multimesh gillnet catch, in order to simplify comparisons between the fish catches of different years. The regression model is based on a test fishing carried out to compare the catches of the two gillnet types in Lake Pohjalampi, eastern Finland in 1995 (own unpublished data). The net selectivity and catchability of the gillnet series in the sampling of perch and roach do not differ from those of the multimesh gillnet (Kurkilahti and Rask, 1996).

At the laboratory the fish in each gillnet were identified to determine species, and their fresh mass (FM) was weighed. The perch caught in 1983, 1986, 1989, 1992, 1998 and 2005 were also measured for total length $(T L)$. Condition factors (Bolger and Connolly, 1989) were calculated for them employing the formula:

$$
K=100 \times \frac{F M}{T L^{b}}
$$

where $K$ is the condition factor, $F M$ is fresh mass $(\mathrm{g}), T L$ is total length $(\mathrm{cm})$ and $b$ is the slope of the linear regression between $\log _{10} F M$ and $\log _{10} T L$ fitted to the data pooled over the sampling sites and the years of sampling. In addition to the condition factors the backcalculated lengths at age-1 were also calculated for the perch caught in 1983, 1986, 1989 and 1992. The perch were aged from their scales. Two-way analysis of variance (two-way ANOVA) was used to test differences in the condition factors of the perch across the four sampling sites (three northern, affected sites: Jokisuu, Noljakansaaret and Ylämylly and one southern, reference site: Pyhäsaari) and the years of sampling (1983, 1986, 1989, 1992, 1998 and 2005). The sampling site and year of sampling were used as fixed factors in the ANOVA. 
If the effect of sampling site or year of sampling on the condition factors was statistically significant $(P<0.05)$, a post hoc test (Tukey's HSD test) was conducted. Perch feed mainly on zooplankton in early life and then switch to zoobenthos and eventually to fish (ontogenetic niche shifts) (Hjelm et al., 2000). For this reason, the ANOVA was performed separately for the "zooplanktivorous" ( $T L<13 \mathrm{~cm}$ ), "omnivorous" $(T L 13-18 \mathrm{~cm})$ and "piscivorous" $(T L>18 \mathrm{~cm})$ perch. In this context, zooplanktivorous refers to the perch individuals that feed mainly on zooplankton, omnivorous to the perch that feed on zooplankton, zoobenthos and fish and piscivorous to the perch that feed mainly on fish (Horppila et al., 2000; Holopainen et al., 2008). Univariate analysis of covariance (ANCOVA) was used to test differences in the lengths at age-1 of the perch caught in 1983, 1986, 1989 and $1992(n=693)$ across the years of hatching (1977-1989) and sampling sites (Jokisuu, Noljakansaaret, Ylämylly and Pyhäsaari). The sampling site and year of hatching were used as fixed factors and the age of perch as a covariate in the ANCOVA. Perch younger than 2+ and older than 9+ years old were excluded from the analysis. When necessary, the dependent variables (the condition factors and lengths at age-1) were $\log _{10}$-transformed to meet the assumptions of ANOVA and ANCOVA.

\section{RESULTS}

\section{$>$ WATER QUALITY}

The annual mean concentrations of chlorophyll $a$ and total phosphorus in summer (JulyAugust) were both higher in the northern part of Lake Pyhäselkä, i.e. in the affected area (the sampling site Noljakansaaret), than in the southern reference area (Pyhäsaari) (Figure 2, Table I). The mean primary production of phytoplankton and bacteria was also higher in the affected area than in the reference area (Figure 2, Table I). The mean concentration of total nitrogen was higher in the reference area than in the affected area (Table I). The water colour was lower and the Secchi depth higher in the reference area than in the affected area, indicating clearer surface water in the reference area (Figure 2, Table I). The highest annual values of total phosphorus concentration, chlorophyll a concentration and primary production of phytoplankton and bacteria were observed in the late 1970s and 1980s (Figure 2). These parameters indicate the overall trophic status of the lake (Huovinen et al., 1993; Mononen and Niinioja, 1993; Pietiläinen and Niinioja, 2000). The annual mean surface water temperature (sampling depth $1 \mathrm{~m}$ ) in summer (July-August) showed an increasing trend, both in the northern and in the southern part of Lake Pyhäselkä during the monitored period from 1975 to the present (Figure 2). No difference in temperature between the affected sampling site, Noljakansaaret, and the reference sampling site, Pyhäsaari, was found (Table I).

\section{$>$ FISH}

Perch and roach were the most abundant fish species in the gillnet catch (Table II). The proportion of perch in the total gillnet catch biomass was $47 \%$ in the affected area (the sampling sites Jokisuu, Noljakansaaret and Ylämylly) and 59\% in the reference area (Pyhäsaari). The proportion of roach in the total catch biomass was $26 \%$ in the affected area and $12 \%$ in the reference area. The mean catch-per-unit-effort (CPUE; kg gillnet.series ${ }^{-1}$.night $^{-1}$ ) of cyprinids, including roach, dace (Leuciscus leuciscus), bream, bleak (Alburnus alburnus), silver bream (Blicca bjoerkna) and ide (Leuciscus idus), was higher in the affected area than in the reference area (Table I). The CPUE of cyprinids was positively related to the concentration of chlorophyll a (Figure 3). The best-fit relationship between the CPUE of cyprinids and the chlorophyll a concentration was the linear regression: $y=0.329 x-0.143\left(F_{1,70}=4.085, P<0.05\right)$, where $y$ is the CPUE of cyprinids pooled over the four sampling sites (the three affected sites and the reference site) and $x$ is the 3rd order moving average of the yearly means of the chlorophyll a values (Figure 3). The mean CPUE of percids, including perch, ruffe (Gymnocephalus cernuus) and pikeperch, did not differ between the affected and the reference area (Table I). In the data 


\section{Table I}

Mean $\pm S D$ chlorophyll a concentration $\left(\mu g \cdot L^{-1}\right)$, water colour $\left(m g P t \cdot L^{-1}\right)$, primary production of phytoplankton and bacteria (mg $\left.C \cdot m^{-3} \cdot d^{-1}\right)$, Secchi depth $(m)$, temperature $\left({ }^{\circ} \mathrm{C}\right)$ of surface water (sampling depth $1 \mathrm{~m}$ ), total nitrogen concentration $\left(\mu \mathrm{g} \cdot \mathrm{L}^{-1}\right)$, total phosphorus concentration $\left(\mu \mathrm{g} \cdot \mathrm{L}^{-1}\right)$ and catchper-unit-effort (CPUE; kg gillnet.series ${ }^{-1} \cdot$ night $^{-1}$ ) of percids and cyprinids in the area affected by the nutrient-rich sewage discharge from a pulp mill and the town of Joensuu and the reference area in Lake Pyhäselkä in 1975-2005. The water temperature and primary production were measured several times every year in July and August. The gillnet fishing was carried out approximately every third year in May and June in 1978-2005. Paired samples t-tests were performed for the variables listed in the table below between the affected and reference area. Statistical differences are indicated as follows: $n s=$ non-significant, ${ }^{*}=P<0.05,{ }^{* *}=P<0.01$ and ${ }^{* *} P<0.001$.

\section{Tableau}

Moyennes \pm SD des concentrations en chlorophylle a $\left(\mu \mathrm{g} \cdot \mathrm{L}^{-1}\right)$, couleur de l'eau $\left(\mathrm{mg} \mathrm{Pt} \cdot \mathrm{L}^{-1}\right)$, production du phytoplancton et des bactéries $\left(\mathrm{mg} \mathrm{C} \cdot \mathrm{m}^{-3} \cdot \mathrm{d}^{-1}\right)$, profondeur du Secchi $(\mathrm{m})$, température $\left({ }^{\circ} \mathrm{C}\right)$ de l'eau en surface (profondeur d'échantillonnage à $1 \mathrm{~m})$, concentration en azote total ( $\mathrm{ug} \cdot \mathrm{L}^{-1}$ ), concentration en phosphore total $\left(\mu \mathrm{g} \cdot \mathrm{L}^{-1}\right)$ et captures par unité d'effort (CPUE; kg série de filets ${ }^{-1}$.nuit ${ }^{-1}$ ) de percidés et cyprinidés dans la zone affectée par les effluents de papèterie et de la ville de Joensuu et dans la zone de référence dans le lac Pyhäselkä de 1975 à 2005. La température de l'eau et la production primaire ont été mesurées plusieurs fois chaque année en juillet et août. La pêche aux filets maillants a été faite environ tous les trois ans en mai et juin de 1978 à 2005. Les tests t pour échantillons appariés ont été réalisés sur les variables listées dans la table ci-dessous entre les zones impactées et celle de référence. Les différences sont indiquées comme suit : ns = non significatif, ${ }^{*}=P<0,05 ;{ }^{* *}=P<0,01$ et ${ }^{* * *} P<0,001$.

\begin{tabular}{|l|c|c|c|c|c|}
\hline \multirow{2}{*}{ Variable } & \multicolumn{2}{|c|}{ Affected area } & \multicolumn{2}{c|}{ Reference area } & Difference \\
\cline { 2 - 6 } & Mean & SD & Mean & SD & \\
\hline Chlorophyll a & 6.7 & 2.1 & 4.7 & 1.2 & ${ }^{* \star *}$ \\
\hline & & & & & \\
\hline Colour & 70 & 15 & 66 & 11 & ${ }^{*}$ \\
\hline & & & & & \\
\hline Primary production & 114 & 59 & 87 & 44 & ${ }^{* *}$ \\
\hline & & & & & \\
\hline Secchi depth & 2.1 & 0.3 & 2.4 & 0.4 & ${ }^{* *}$ \\
\hline & & & & & \\
\hline Temperature & 17.9 & 1.3 & 17.7 & 1.5 & ns \\
\hline & & & & & \\
\hline Total nitrogen & 414 & 47 & 440 & 75 & ${ }^{*}$ \\
\hline & & & & & \\
\hline Total phosphorus & 15 & 4 & 13 & 3 & ${ }^{* * *}$ \\
\hline CPUE of percids & 2.802 & 2.002 & 4.058 & 4.651 & ns \\
\hline & & & & & \\
\hline CPUE of cyprinids & 2.012 & 2.001 & 0.873 & 0.893 & ${ }^{*}$ \\
\hline
\end{tabular}

pooled over the sampling sites, the CPUE of percids was positively related to water temperature (Figure 3). The best-fit relationship between the CPUE of percids and surface water temperature was the exponential function: $y=0.004 \times \mathrm{e}^{(0.365 x)}\left(F_{1,80}=14.075, P<0.001\right)$, where $y$ is the CPUE of percids pooled over the four sampling sites and $x$ is the 3rd order moving average of the yearly means of the water temperature values (Figure 3). The mean CPUE of salmonids was very low, both in the affected area $\left(0.304 \pm 0.292 \mathrm{~kg}\right.$ gillnet.series ${ }^{-1}$.night ${ }^{-1}$, mean $\pm \mathrm{SD})$ and in the reference area $\left(0.327 \pm 0.547 \mathrm{~kg}\right.$ gillnet. series ${ }^{-1} \cdot$ night $^{-1}$, mean $\left.\pm \mathrm{SD}\right)$. The most abundant salmonid in the total gillnet catch was whitefish.

The year of sampling had an effect on the condition factors of the perch caught in 1983 (number of fish $(n)=78), 1986(n=25), 1989(n=128), 1992(n=149), 1998(n=63)$ and $2005(n=147)$ in all three size categories $(T L<13 \mathrm{~cm}, T L 13-18 \mathrm{~cm}$ and $T L>18 \mathrm{~cm})$ (Figure 4, Table III). According to the post hoc test (Tukey's HSD), the condition factors of the zooplanktivorous perch $(T L<13 \mathrm{~cm})$ caught in 1983 and 2005 were lower than those of the perch caught in $1989(P<0.001$ and $P<0.01)$. The condition factors of the omnivorous 


\section{Table II}

Mean catch-per-unit-effort (kg gillnet.series ${ }^{-1} \cdot$ night $^{-1}$ ) of fish caught in Lake Pyhäselkä in 1978-2005. The fishing was carried out in the area affected by industrial and municipal sewage discharge ( $A$; three sampling sites) and in the reference area (R; one sampling site) in May and June.

\section{Tableau II}

Captures moyennes par unité d'effort $\left(\mathrm{kg}\right.$ série de filets ${ }^{-1} \cdot$ nuit $\left.^{-1}\right)$ de poissons capturés dans le lac Pyhäselkä de 1978 à 2005. La pêche a été réalisée dans la zone affectée par les effluents industriels et domestiques ( $\mathrm{A}$; trois sites d'échantillonnage) et dans la zone de référence ( $\mathrm{R}$; un site d'échantillonnage) en mai et juin.

\begin{tabular}{|c|c|c|c|c|c|c|c|c|}
\hline \multirow{2}{*}{$\begin{array}{l}\text { Year } \\
\text { (Area) }\end{array}$} & \multicolumn{8}{|c|}{ Fish species } \\
\hline & Perch & Ruffe & Pikeperch & Roach & Dace & Bream & Whitefish & Others \\
\hline $1978(A)$ & 1.288 & 0.168 & no catch & 0.224 & 0.128 & 0.056 & 0.208 & 0.072 \\
\hline $1981(\mathrm{~A})$ & 1.144 & 0.328 & 0.040 & 1.192 & 1.264 & no catch & 0.176 & 0.336 \\
\hline $1983(\mathrm{~A})$ & 1.472 & 0.176 & no catch & 0.408 & 0.696 & no catch & 0.216 & 0.096 \\
\hline $1986(\mathrm{~A})$ & 2.864 & 0.280 & no catch & 2.608 & 1.024 & no catch & 0.232 & 0.240 \\
\hline 1989 (A) & 2.592 & 0.040 & 0.224 & 1.976 & 0.080 & 0.088 & 0.136 & 0.040 \\
\hline $1992(\mathrm{~A})$ & 3.064 & 0.096 & 0.048 & 2.400 & 0.176 & 0.136 & 0.224 & 0.272 \\
\hline 1995 (A) & 3.616 & 0.304 & 0.368 & 1.168 & 0.120 & 0.968 & 0.520 & 0.328 \\
\hline 1998 (A) & 2.560 & 0.232 & 0.168 & 1.072 & 0.320 & 0.088 & 0.264 & 0.120 \\
\hline 2002 (A) & 4.632 & 0.192 & 0.392 & 1.440 & 0.192 & no catch & 0.352 & 0.368 \\
\hline 2005 (A) & 2.208 & 0.192 & 0.416 & 1.328 & 0.224 & no catch & 0.272 & 0.624 \\
\hline & & & & & & & & \\
\hline 1981 (K) & 1.416 & $\frac{0.040}{1176}$ & 0.016 & 0.488 & 0.280 & no catch & $\frac{0.104}{0.024}$ & $\frac{0.008}{0.47 ?}$ \\
\hline 1989 (R) & 0.888 & 0.728 & 0.368 & no catch & no catch & no catch & 0.320 & 0.424 \\
\hline $1992(\mathrm{R})$ & 9.216 & 0.080 & 0.928 & 0.648 & no catch & no catch & 1.112 & no catch \\
\hline 1995 (R) & 1.968 & 0.112 & 0.152 & 0.720 & 0.048 & no catch & 0.096 & 0.256 \\
\hline 1998 (R) & 3.024 & 0.208 & 0.656 & 0.496 & 0.216 & no catch & 0.360 & 0.312 \\
\hline 2002 (R) & 5.312 & 0.216 & no catch & 2.200 & 0.200 & no catch & no catch & 1.024 \\
\hline 2005 (R) & 3.792 & 0.304 & 0.536 & 1.304 & 0.104 & 0.504 & no catch & 0.888 \\
\hline
\end{tabular}
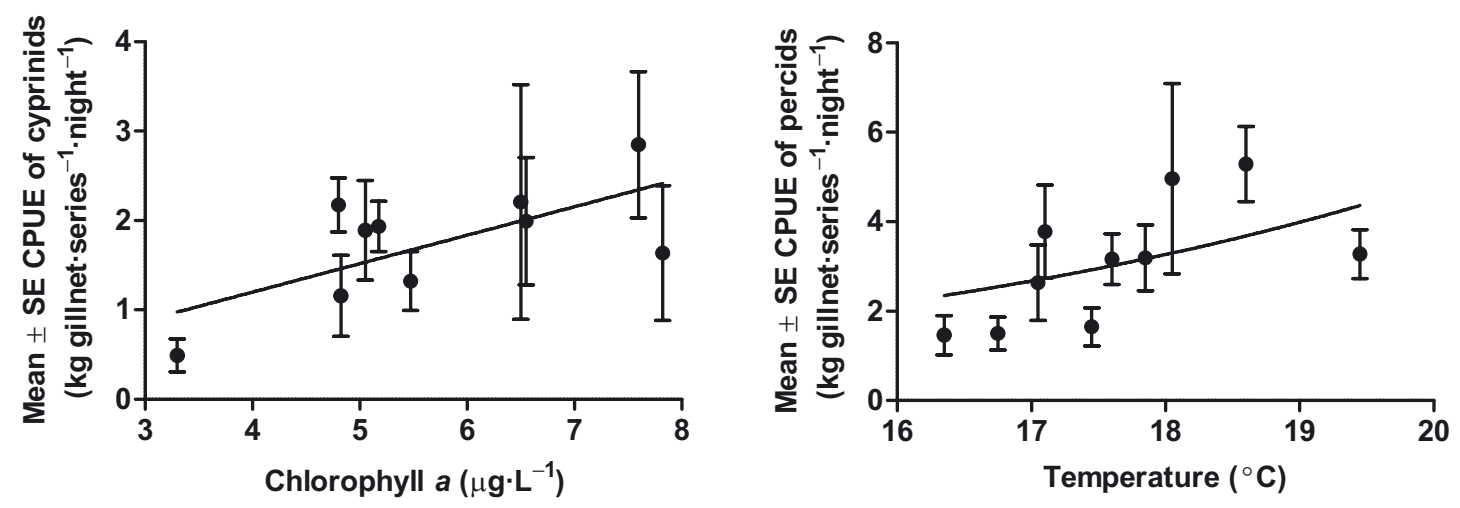

\section{Figure 3}

Mean \pm SE catch-per-unit-effort (CPUE; kg gillnet-series ${ }^{-1}$.night ${ }^{-1}$ ) of cyprinids pooled over the four sampling sites in relation to chlorophyll a concentration (on the left) and that of percids in relation to surface water temperature (on the right) in Lake Pyhäselkä. The test fishing was carried out approximately every third year between 1978 and 2005. The chlorophyll a and temperature values denote the 3rd order moving average of the yearly means.

\section{Figure 3}

Moyenne \pm SE des captures par effort (CPUE; kg série de filets ${ }^{-1} \cdot$ nuit $^{-1}$ ) des cyprinidés pour les quatre sites rassemblés en relation avec la concentration en chlorophylle a (à gauche) et celles des percidés en relation avec la température de surface dans le lac Pyhäselkä. La pêche aux filets maillants a été faite environ tous les trois ans en mai et juin de 1978 à 2005. Les valeurs de température et de chlorophylle sont des moyennes mobiles sur trois ans des moyennes annuelles. 


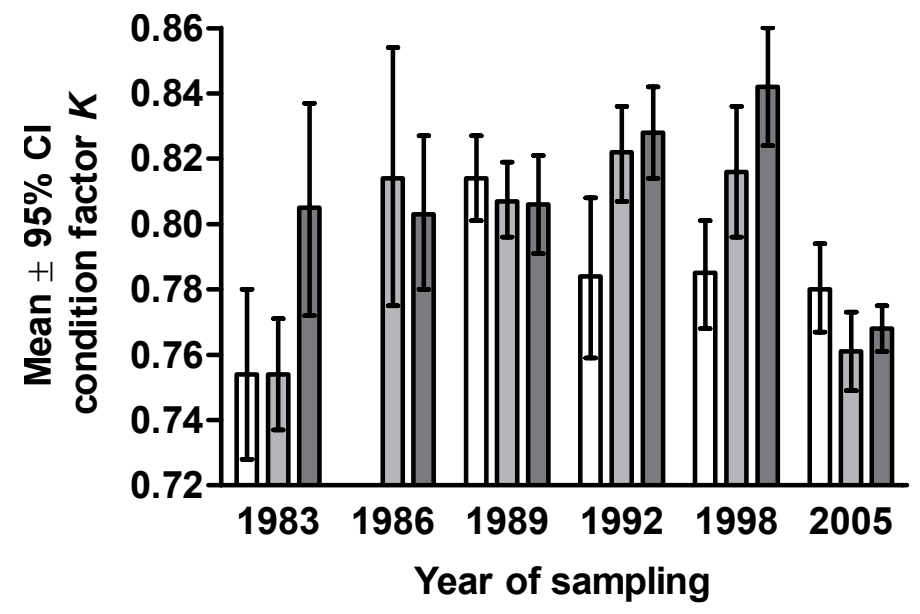

\title{
Figure 4
}

Mean (and its 95\% confidence interval) condition factors $K$ of the perch caught in Lake Pyhäselkä in 1983, 1986, 1989, 1992, 1998 and 2005. The different size categories of the perch are indicated as follows: white bars = total length $(T L)<13 \mathrm{~cm}$, light grey bars $=T L 13-18 \mathrm{~cm}$ and dark grey bars $=T L$ $>18 \mathrm{~cm}$. Only five small perch $(T L<13 \mathrm{~cm})$ were caught in 1986 and, therefore, the size category in 1986 is omitted from the figure. For the statistical differences in $K$ between the years of sampling and size categories of the perch see text and Table III.

\begin{abstract}
Figure 4
Moyennes (et intervalle de confiance à $95 \%$ ) des facteurs de condition $\mathrm{K}$ des perches capturées dans le lac Pyhäselkä en 1983, 1986, 1989, 1992, 1998 et 2005. Les différentes catégories de taille des perches sont indiquées comme suit : barres blanches $T L<13 \mathrm{~cm}$, barres gris clair $=T L 13-18 \mathrm{~cm}$ et barres gris foncé $=T L>18 \mathrm{~cm}$. Seulement cinq perches $(T L<13 \mathrm{~cm})$ ont été capturées en 1986 et, par conséquent, cette catégorie a été exclue de la figure. Pour les différences statistiques entre année et catégorie de taille de perche, voir le texte et le tableau III.
\end{abstract}

perch (TL 13-18 cm) caught in 1983 and 2005 were lower than those of the perch caught in $1986(P<0.001$ and $P<0.01), 1989(P<0.001$ and $P<0.001), 1992(P<0.001$ and $P<0.001)$ and $1998(P<0.001$ and $P<0.05)$. The condition factors of the piscivorous perch $(T L>18 \mathrm{~cm})$ caught in 2005 were lower than those of the perch caught in $1986(P<0.05)$, $1989(P<0.001), 1992(P<0.001)$ and $1998(P<0.001)$. In addition, the condition factors of the piscivorous perch caught in 1989 were lower than those of the perch caught in 1998 $(P<0.01)$. The sampling site (Jokisuu, Noljakansaaret, Ylämylly and Pyhäsaari) had an effect on the condition factors of the perch only in the category of omnivorous perch (Table III). However, according to the post hoc test (Tukey's HSD), none of the individual differences between the four sampling sites were significant. Thus, the condition factors of the perch caught in the affected area (Jokisuu, Noljakansaaret and Ylämylly) were compared to those of the perch caught in the reference area (Pyhäsaari) (two-way ANOVA with a simple contrast). In this new analysis, the condition factors of the omnivorous perch caught in the reference area were lower than those of the perch caught in the affected area $\left(F_{3,566}=2.694, P<0.05\right)$. The interaction of site and year of sampling had an effect on the condition factors of the zooplanktivorous and omnivorous perch (Table III).

The effect of sampling site (Jokisuu, Noljakansaaret, Ylämylly and Pyhäsaari) on the lengths at age-1 of perch caught in 1983,1986, 1989 and 1992 was significant, whereas the effect of year of hatching (1977-1989) was not (Table IV). The length at age-1 of the perch caught in the affected area (6.0; 5.9-6.1 cm, mean; 95\% confidence interval) was lower than that of the perch caught in the reference area $(6.3 ; 6.2-6.5 \mathrm{~cm})\left(t\right.$-test, $\left.t_{740}=5.461, P<0.001\right)$. The difference in length at age-1 between the affected and reference areas was especially large among perch hatched in 1981-1983 (Figure 5). The length at age-1 of the perch did not differ across the three sampling sites in the affected area (ANOVA, $F_{2,553}=2.394, P>0.05$ ). 


\section{Table III}

ANOVA statistics for the condition factors of perch across the years of sampling $(1983,1986,1989,1992$, 1998 and 2005) and the sampling sites (the three affected sites: Jokisuu, Noljakansaaret, Ylämylly and the reference site: Pyhäsaari). The analyses were performed separately for the "zooplanktivorous" (TL < $13 \mathrm{~cm}$, analysis $A$ in the table), "omnivorous" (TL 13-18 cm, analysis B) and "piscivorous" perch (TL > $18 \mathrm{~cm}$, analysis C). Only five "zooplanktivorous" perch were caught in 1986 and, therefore, the year was excluded from the analysis A. Statistical differences (Sig.) are indicated as follows: $n s=$ non-significant, ${ }^{*}=P<0.05,{ }^{* *}=P<0.01$ and ${ }^{* * *} P<0.001$.

\section{Tableau III}

Statistiques ANOVA sur les facteurs de condition des perches entre années d'échantillonnage (1983, 1986, 1989, 1992, 1998 et 2005) et sites d'échantillonnage (trois sites affectés : Jokisuu, Noljakansaaret, Ylämylly et le site de référence : Pyhäsaari). Les analyses ont été réalisées séparément pour les perches "zooplanctonophages » ( $T L<13 \mathrm{~cm}$, analyse A dans le tableau), "omnivores » $(T L 13-18 \mathrm{~cm}$, analyse B), et piscivores (TL > $18 \mathrm{~cm}$, analyse C). Seulement cinq perches "zooplanctonophages » ont été capturées en 1986 et, par conséquent, cette année a été exclue de l'analyse A. Les différences sont indiquées comme suit : $\mathrm{ns}=$ non significatif, ${ }^{*}=P<0,05 ;{ }^{* *}=P<0,01$ et ${ }^{* * *} P<0,001$.

\begin{tabular}{|l|c|c|c|c|c|c|}
\hline Analysis & Source of variation & Sum of squares & df & Mean square & $F$ & Sig. \\
\hline A & Year of sampling & 0.080 & 4 & 0.020 & 6.368 & ${ }^{\star * *}$ \\
\hline & Sampling site & 0.015 & 3 & 0.005 & 1.628 & $\mathrm{~ns}$ \\
\hline & Interaction (year $\times$ site) & 0.085 & 10 & 0.009 & 2.732 & ${ }^{* *}$ \\
\hline & & & & & & \\
\hline B & Year of sampling & 0.315 & 5 & 0.063 & 14.784 & ${ }^{\star * *}$ \\
\hline & Sampling site & 0.034 & 3 & 0.011 & 2.694 & ${ }^{*}$ \\
\hline & Interaction (year $\times$ site) & 0.156 & 15 & 0.010 & 2.445 & ${ }^{* *}$ \\
\hline C & & & & & & \\
\hline & Year of sampling & 0.393 & 5 & 0.079 & 20.611 & ${ }^{\star * *}$ \\
\hline & Sampling site & 0.012 & 3 & 0.004 & 1.058 & $\mathrm{~ns}$ \\
\hline
\end{tabular}

\section{Table IV}

ANCOVA statistics for the lengths at age-1 of perch across the sampling sites (the three affected sites: Jokisuu, Noljakansaaret, Ylämylly and the reference site: Pyhäsaari) and years of hatching (1977-1989). The age of the fish was used as a covariate in the analysis. Statistical differences (Sig.) are indicated as follows: $n s=$ non-significant, ${ }^{*}=P<0.05,{ }^{* *}=P<0.01$ and ${ }^{* * *} P<0.001$.

\section{Tableau IV}

Statistiques ANOVA pour les longueurs des perches à l'âge d'1 an entre les sites d'échantillonnage (trois sites affectés : Jokisuu, Noljakansaaret, Ylämylly et le site de référence : Pyhäsaari) et les années de naissance (1977-1989). L'âge des poissons a été utilisé comme covariable dans l'analyse. Les différences sont indiquées comme suit : ns $=$ non significatif, ${ }^{*}=P<0,05 ;{ }^{* *}=P<0,01$ et ${ }^{* * *} P<0,001$.

\begin{tabular}{|l|c|c|c|c|c|}
\hline Source of variation & Sum of squares & $\mathrm{df}$ & Mean square & $F$ & Sig. \\
\hline Sampling site & 9.793 & 3 & 3.264 & 6.512 & ${ }^{\star \star \star}$ \\
\hline Year of hatching & 8.271 & 12 & 0.689 & 1.375 & $\mathrm{~ns}$ \\
\hline Interaction (site $\times$ year) & 36.244 & 33 & 1.098 & 2.191 & ${ }^{\star \star \star}$ \\
\hline Age & 0.435 & 1 & 0.435 & 0.867 & $\mathrm{~ns}$ \\
\hline
\end{tabular}

\section{DISCUSSION}

According to the water quality parameters indicating a lake's trophic state - the total phosphorus concentration and specifically the chlorophyll a concentration and the primary production of phytoplankton and bacteria - the northern part of Lake Pyhäselkä was clearly mesotrophic in the 1980s as a consequence of nutrient-rich sewage discharges from the Enocell pulp mill into the River Pielisjoki and further into the Lake Pyhäselkä. The higher nutrient input favoured cyprinids, especially roach, but also dace. More cyprinids were caught at the affected northern sites of Lake Pyhäselkä than at the southern reference site (Table II). On the other hand, the abundance of percids had no clear association with the trophic status. These observations concerning the effects of pulp mill effluents on the fish community of Lake Pyhäselkä 


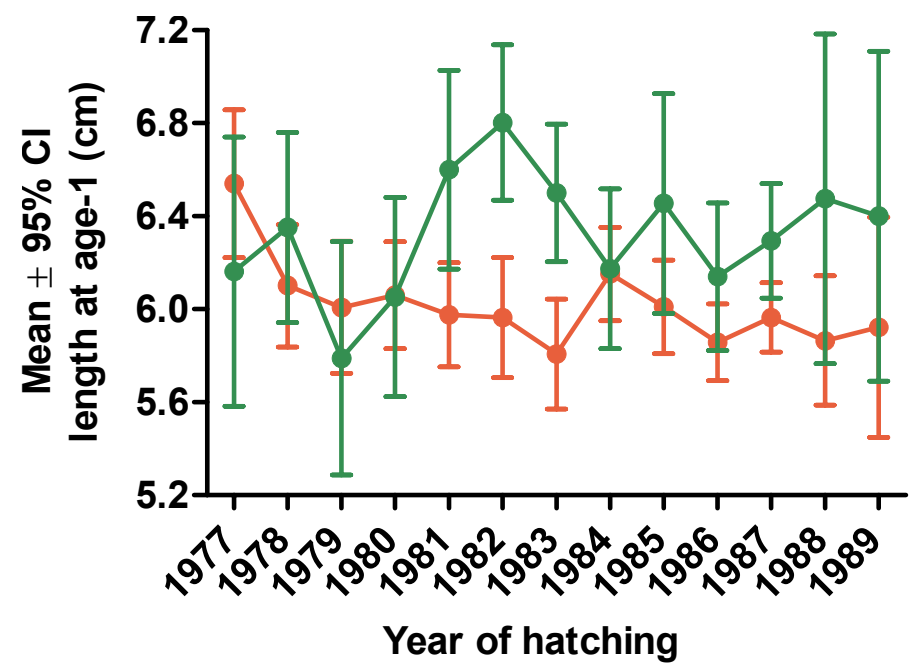

\section{Figure 5}

Mean (and its 95\% confidence interval) lengths at age-1 of the perch hatched in 1977-1989. The fish were caught either in the area affected by the nutrient-rich sewage discharge (red symbols and line) or in the reference area (green symbols and line) in Lake Pyhäselkä. For the statistical differences in lengths at age-1 of the perch between sites of sampling and years of hatching see text and Table IV.

\section{Figure 5}

Moyennes (et intervalle de confiance à 95 \%) des longueurs à 1 an des perches nées de 1977 à 1989 . Les poissons ont été capturés dans les zones affectées par les effluents (symboles et ligne rouges) ou la zone de référence (symboles et ligne verts) dans le lac Pyhäselkä. Pour les différences statistiques entre longueurs à 1 an et années de naissance des perches, voir le texte et le tableau IV.

are in accordance with the results of surveys carried out in central Finland (Hakkari, 1992) and along the Baltic coast of Sweden (Hansson, 1987). It must be noted, however, that the phosphorus gradient was quite narrow in Lake Pyhäselkä through most of the monitoring period. Helminen et al. (2000) observed that cyprinids became dominant in Finnish lakes when the total phosphorus concentration exceeded $30 \mu \mathrm{g} \cdot \mathrm{L}^{-1}$.

The mean length at age-1 of the perch caught in the affected area of Lake Pyhäselkä was less than that of conspecifics caught in the reference area - specifically in the 1980s (Figure 5). The length at age- 1 indicates the growth of fish during their first growing season. The growth rate of fish is highly dependent on fish density (Boisclair and Leggett, 1989a) and type of available food (Boisclair and Leggett, 1989b). In a fish community dominated by perch and roach, the competitive interactions between these two species cause shifts in the diet of $0+$ and $1+$ perch from pelagic zooplankton to benthic macroinvertebrates (Persson, 1987; Persson and Greenberg, 1990). This, in turn, strengthens food competition among the benthivorous perch (Persson and Greenberg, 1990). Moreover, if the roach are able to utilise plant and detrital material in large quantities, as they usually do in the case of meso- or eutrophy, the roach population grows faster than the perch population and the strength of competitive effects on the perch increases further (Persson, 1983). Consequently, it is suggested that the observed short lengths at age- 1 of the perch caught at the affected sites of Lake Pyhäselkä, as well as the low condition factors of the small- and medium-sized perch $(T L \leq 18 \mathrm{~cm})$ in the early 1980s (Figure 4), were a result of the strong inter- and intraspecific competitive pressure on the zooplanktivorous and benthivorous perch. The abundance of perch in ponds and lakes has been showed to be related to biotic factors, and especially to the abundance of roach (Sumari, 1971; Persson, 1997; Olin et al., 2002).

In the data pooled over all four sampling sites (three northern affected sites and the southern reference site) in Lake Pyhäselkä, the abundance of percids associated positively with surface water temperature (Figure 3). Perch is a warm water species (Hokanson, 1977), and increased water temperature improves its foraging ability (Bergman, 1987). Perch populations 
derive benefit from higher water temperatures in terms of increased individual growth rates and reduced mortality caused by predation during the first growing season (Lappalainen et al., 1996). The condition factors of the perch caught in the 1990s were somewhat higher than those of the perch caught in the 1980s - especially in the case of larger perch (TL $\geq 13 \mathrm{~cm})$ (Figure 4). The competitive pressure on the perch was supposedly lower in 1990s than in 1980s due to the decreased nutrient input into the lake and higher water temperatures, both of which favour the growth of perch individuals. Interestingly, the condition factors of the perch caught in 2005 were much lower than those of the perch caught in earlier surveys in the 1980s and 1990s - again, especially in the case of larger perch (TL $\geq 13 \mathrm{~cm}$ ) (Figure 4). Exceptionally strong intraspecific competition between the larger perch in 2005 does not explain the result since the mean CPUE of perch in $2005\left(2.608 \mathrm{~kg}\right.$ gillnet.series ${ }^{-1} \cdot$ night $\left.^{-1}\right)$ was not higher than that in 1983-1998 $\left(2.736 \mathrm{~kg}\right.$ gillnet.series ${ }^{-1} \cdot$ night $\left.^{-1}\right)$. A possible reason for the observed low condition factors of the larger perch caught in 2005 could be the substantially increased abundance of pikeperch in Lake Pyhäselkä in the early years of the 21 st century. According to catch statistics of local fishermen, the average CPUE of large piscivorous pikeperch was over twofold in 2001-2005 compared to that of the 1990s (own unpublished data). Pikeperch is a valuable species for commercial fisheries and large numbers of pikeperch have been stocked in Lake Pyhäselkä during the past few decades. Moreover, the rising water temperatures as well as the darkening of water will also benefit pikeperch (Keskinen and Marjomäki, 2003; Lappalainen et al., 2005). Pikeperch prey effectively on small perch (Keskinen and Marjomäki, 2004). This increased predation may affect the population size of perch (Dörner et al., 2007). Cannibalism is common among perch and usually the growth rates and fecundity of the large cannibalistic individuals are especially high (Persson et al., 2000). The increased predation on small perch by pikeperch may thus strengthen the competitive pressure on the large piscivorous perch and lower their condition factors.

To conclude, two fundamental processes have altered the water quality and fish community of Lake Pyhäselkä during the last four decades. First, the lake's trophic state proceeded from oligotrophic to mesotrophic in the 1980s as a result of the nutrient-rich sewage discharges from the Enocell pulp mill and the town of Joensuu. The mesotrophic state favoured cyprinids, mainly roach but also dace. The increased cyprinid density in the affected northern area of Lake Pyhäselkä strengthened the competition pressure on perch, the predominant species in the fish community. This, in turn, reduced the growth rates of young perch during their first growing season. The lake's trophic state shifted from mesotrophic back to oligotrophic in the 1990s due to more effective treatment of the industrial and municipal sewage waters. Second, the mean surface water temperature in Lake Pyhäselkä in summer (July-August) has shown a clear rising trend since the beginning of the monitoring period. In general, warming increases the growth of all fish but, at the population and community levels, it benefits the warm water species, such as perch. In Lake Pyhäselkä the abundance of perch related positively to the water temperature. However, it is possible that warming favours pikeperch even more than perch. This may have major effects on the perch populations, as pikeperch prey effectively on small perch. In the future, more intensive study of the interactions between warming climate and human stressors, such as sewage discharge causing eutrophication, is needed in order to generate precise predictions of the effects arising from climatic change on ecosystems.

\section{ACKNOWLEDGEMENTS}

We thank R. Niinioja of the North Karelia Centre for Economic Development, Transport and the Environment for supplying the data from the Hertta database and K. Kyyrönen for drawing the map figure. We also thank A.-L. Holopainen, who is retired, but kindly permitted us to use her outstanding data. The samplings were carried out by numerous diligent field workers, and their help is gratefully acknowledged. Furthermore, we thank two anonymous reviewers for their valuable comments and Rosemary Mackenzie for revising the English. The study has been financially supported by the Academy of Finland (Project 14159). 


\section{REFERENCES}

Bagge P. and Hakkari L., 1992. Effects of paper mill effluents on the fish fauna of stony shores of Lake Päijänne. Hydrobiologia, 243/244, 413-420.

Bergman E., 1987. Temperature-dependent differences in foraging ability of two percids, Perca fluviatilis and Gymnocephalus cernuus. Environ. Biol. Fish., 19, 45-53.

Boisclair D. and Leggett W.C., 1989a. Among-population variability of fish growth: III. Influence of fish community. Can. J. Fish. Aquat. Sci. , 46, 1539-1550.

Boisclair D. and Leggett W.C., 1989b. Among-population variability of fish growth: II. Influence of prey type. Can. J. Fish. Aquat. Sci., 46, 468-482.

Bolger T. and Connolly P.L., 1989. The selection of suitable indices for the measurement and analysis of fish condition. J. Fish Biol., 34, 171-182.

Dörner H., Hülsmann S., Hölker F., Skov C. and Wagner A., 2007. Size-dependent predator-prey relationships between pikeperch and their prey fish. Ecol. Freshw. Fish, 16, 307-314.

Gyllström M., Hansson L.-A., Jeppesen E., Garcia-Criado F., Gross E., Irvine K., Kairesalo T., Kornijow R., Miracle M.R., Nykänen M., Nõges T., Romo S., Stephen D., Van Donk E. and Moss B., 2005. The role of climate in shaping zooplankton communities of shallow lakes. Limnol. Oceanogr., 50, 2008-2021.

Hakkari L., 1992. Effects of pulp and paper mill effluents on fish populations in Finland. Finnish Fish. Res., 13, 93-106.

Hakkari L. and Bagge P., 1992. Reproductive success of Coregonus species in areas loaded by effluents from paper mills. Hydrobiologia, 243/244, 405-412.

Hansson S., 1987. Effects of pulp and paper mill effluents on coastal fish communities in the Gulf of Bothnia, Baltic Sea. Ambio, 16, 344-348.

Helminen H., Karjalainen J., Kurkilahti M., Rask M. and Sarvala J., 2000. Eutrophication and fish biodiversity in Finnish lakes. Verh. Internat. Verein. Limnol., 27, 194-199.

Hjelm J., Persson L. and Christensen B., 2000. Growth, morphological variation and ontogenetic niche shifts in perch (Perca fluviatilis) in relation to resource availability. Oecologia, 122, 190-199.

Hokanson K.E.F., 1977. Temperature requirements of some percids and adaptations to the seasonal temperature cycle. J. Fish Res. Board Can., 34, 1524-1550.

Holopainen I.J., Aroviita J., Voutilainen A. and Viljanen M., 2008. Biomass, growth, and diet of fish in forest lakes affected by alkaline mining water in NW Russia. Est. J. Ecol., 57, 256-268.

Horppila J., Ruuhijärvi M., Rask M., Karppinen C., Nyberg K. and Olin M., 2000. Seasonal changes in the diets and relative abundances of perch and roach in the littoral and pelagic zones of a large lake. J. Fish Biol., 56, 51-72.

Huovinen P., Holopainen A.-L. and Huttunen P., 1993. Spatial variation of community respiration and primary productivity in two large lakes in Eastern Finland. Verh. Internat. Verein. Limnol., 25, 552556.

Huuskonen H., Holopainen A.-L., Hämäläinen H., Karjalainen J., Leppä M., Punta E. and Rahkola M., 2000. Eutrophication and recovery - positive effects of the modernization of a pulp mill. In: Ruoppa M., Paasivirta J., Lehtinen K.-J. and Ruonala S. (eds.), 4th International conference on environmental impacts of the pulp and paper industry, Proceedings of the conference 12-15 June 2000 Helsinki, Finland, The Finnish Environment, 417, Finnish Environment Institute, Helsinki, 329-334.

Jansen W. and Hesslein R.H., 2004. Potential effects of climate warming on fish habitats in temperate zone lakes with special reference to Lake 239 of the experimental lakes area (ELA), north-western Ontario. Environ. Biol. Fish., 70, 1-22.

Karels A.E. and Niemi A., 2002. Fish community responses to pulp and paper mill effluents at the southern Lake Saimaa, Finland. Environ. Pollut., 116, 309-317.

Karels A., Markkula E. and Oikari A., 2001. Reproductive, biochemical, physiological, and population responses in perch (Perca fluviatilis L.) and roach (Rutilus rutilus L.) downstream of two elemental chlorine-free pulp and paper mills. Environ. Toxicol. Chem., 20, 1517-1527.

Keskinen T. and Marjomäki T.J., 2003. Growth of pikeperch in relation to lake characteristics: total phosphorus, water colour, lake area and depth. J. Fish Biol., 63, 1274-1282.

Keskinen T. and Marjomäki T.J., 2004. Diet and prey size spectrum of pikeperch in lakes in central Finland. J. Fish Biol., 65, 1147-1153. 
Kurkilahti M. and Rask M., 1996. A comparative study of the usefulness and catchability of multimesh gill nets and gill net series in sampling of perch (Perca fluviatilis L.) and roach (Rutilus rutilus L.). Fish. Res., 27, 243-260.

Lappalainen J. and Lehtonen H., 1997. Temperature habitats for freshwater fishes in a warming climate. Boreal Environ. Res., 2, 69-84.

Lappalainen J. and Soininen J., 2006. Latitudinal gradients in niche breadth and position - regional patterns in freshwater fish. Naturwissenschaften, 93, 246-250.

Lappalainen J., Lehtonen H., Böhling P. and Erm V., 1996. Covariation in year-class strength of perch, Perca fluviatilis L. and pikeperch, Stizostedion lucioperca (L.). Ann. Zool. Fenn., 33, 421-426.

Lappalainen J., Malinen T., Rahikainen M., Vinni M., Nyberg K., Ruuhijärvi J. and Salminen M., 2005. Temperature dependent growth and yield of pikeperch, Sander lucioperca, in Finnish lakes. Fisheries Manag. Ecol., 12, 27-35.

Lehtonen H., 1996. Potential effects of global warming on northern European freshwater fish and fisheries. Fisheries Manag. Ecol., 3, 59-71.

Lehtonen H. and Lappalainen J., 1995. The effects of climate on the year-class variations of certain freshwater fish species. Can. Spec. Publ. Fish Aquat. Sci., 121, 37-44.

MacLean J. and Magnuson J.J., 1977. Species interaction in percid communities. J. Fish Res. Board Can., 34, 1941-1951.

Mononen P. and Niinioja R., 1993. Nutrient and chlorophyll concentrations in the northern part of Lake Saimaa, Finland. Verh. Internat. Verein. Limnol., 25, 544-547.

Olden J.D., Jensen O.P. and Vander Zanden M.J., 2006. Implications of long-term dynamics of fish and zooplankton communities for among-lake comparisons. Can. J. Fish. Aquat. Sci., 63, 1812-1821.

Olin M., Rask M., Ruuhijärvi J., Kurkilahti M., Ala-Opas P. and Ylönen O., 2002. Fish community structure in mesotrophic and eutrophic lakes of southern Finland: the relative abundances of percids and cyprinids along a trophic gradient. J. Fish Biol., 60, 593-612.

Persson L., 1983. Effects of intra- and interspecific competition on dynamics and size structure of a perch Perca fluviatilis and roach Rutilus rutilus population. Oikos, 41, 126-132.

Persson L., 1987. Effects of habitat and season on competitive interactions between roach (Rutilus rutilus) and perch (Perca fluviatilis). Oecologia, 73, 170-177.

Persson L., 1997. Competition, predation and environmental factors as structuring forces in freshwater fish communities: Sumari (1971) revisited. Can. J. Fish. Aquat. Sci., 54, 85-88.

Persson L. and Greenberg L.A., 1990. Juvenile competititve bottlenecks: the perch (Perca fluviatilis)roach (Rutilus rutilus) interaction. Ecology, 71, 44-56.

Persson L., Diehl S., Johansson L., Andersson G. and Hamrin S.F., 1991. Shifts in fish communities along the productivity gradient of temperate lakes - patterns and the importance of size-structured interactions. J. Fish Biol., 38, 281-293.

Persson L., Byström P. and Wahlström E., 2000. Cannibalism and competition in Eurasian perch: population dynamics of an ontogenetic omnivore. Ecology, 81, 1058-1071.

Pietiläinen O.-P. and Niinioja R., 2000. Nitrogen and phosphorus as algal growth limiting factors in a boreal lake. Verh. Internat. Verein. Limnol., 27, 2944-2947.

Schindler D.W., 1997. Widespread effects of climate warming on freshwater ecosystems in North America. Hydrol. Process., 11, 1043-1067.

Schlosser I.J., Johnson J.D., Knotek W.L. and Lapinska M., 2000. Climate variability and size-structured interactions among juvenile fish along a lake-stream gradient. Ecology, 81, 1046-1057.

Sumari O., 1971. Structure of the perch populations of some ponds in Finland. Ann. Zool. Fenn., 8, 406-421.

Tammi J., Appelberg M., Beier U., Hesthagen T., Lappalainen A. and Rask M., 2003. Fish status survey of Nordic lakes: effects of acidification, eutrophication and stocking activity on present fish species composition. Ambio, 32, 98-105. 